\title{
PERBEDAAN DAMPAK HOSPITALISASI PADA ANAK PRASEKOLAH YANG DIDAMPINGI ORANG TUA DAN SELAIN ORANG TUA
}

\section{The Difference Between Hospitalized Impact in Preschool Children Accompanied by Parents And Unaccompanied by Parents}

\author{
Dina Zakiyyatul Fuadah ${ }^{1}$, Diana Rachmania ${ }^{2}$, Sulis $^{3}$ \\ ${ }^{1-3}$ Program Studi Keperawatan, STIKES Karya Husada, Kediri, Jawa Timur, Indonesia \\ Korespondensi : dinazakiyya@gmail.com
}

\begin{abstract}
ABSTRAK
Hospitalisasi seringkali menjadi krisis utama yang dihadapi anak saat menjalani rawat inap di Rumah Sakit bisa menyebabkan anak stress maupun trauma, sehingga menimbulkan respon negative pada anak diantaranya adalah tidak kooperatif pada saat proses perawatan (protes, pemisahan diri, penyangkalan). Salah satu upaya untuk meminimalisir yaitu dengan melakukan pendampingan dari orang tua. Tujuan penelitian ini untuk mengetahui perbedaan dampak hospitalisasi pada anak prasekolah (usia 3-6 tahun) yang didampingi orang tua dan selain orang tua di Ruang Anak Rumah Sakit Amelia Pare. Desain yang digunakan komparatif dengan pendekatan cross sectional didapat sampel 44 responden (22 responden anak yang didampingi orang tua dan 22 responden anak yang didampingi selain orang tua) yang diambil melalui teknik purposive sampling. Hasil penelitian menunjukkan sebagian besar $(81,8 \%)$ responden yang didampingi orang tua memiliki kriteria ringan, sedangkan yang didampingi selain orang tua menunjukan sebagian besar $(72,7 \%)$ dalam kategori berat. Hasil analisis menggunakan uji mann whitney diketahui nilai $p=0,000(\alpha \leq 0,05)$ yang berarti ada perbedaan dampak hospitalisasi pada anak prasekolah yang didampingi orang tua dan selain orang tua di Ruang Anak Rumah sakit Amelia Pare. Pendampingan orang tua sangat berpengaruh pada hospitalisasi anak, sehingga perawat harus melakukan pendekatan terhadap pendamping maupun klien itu sendiri supaya hospitalisasi berjalan dengan baik.
\end{abstract}

Kata kunci: orang tua, anak prasekolah, hospitalisasi.

\section{ABSTRACT}

Hospitalization is often the main crisis faced by children while undergoing hospitalization in hospitals which can cause children to experience stress or trauma, causing negative responses in children including non-cooperation during the treatment process (protest, separation, denial). One of the effort to minimize is by providing assistance from parents. The purpose of this research was to determine The difference in the impact of hospitalized preschool children ( $3-6$ years old) accompanied by parents and un-accompanied by parents in Pediatric room of Amelia general hospital of Pare. The design was used comparative with the cross sectional approach obtained a sample of 44 respondents (22 child respondents who were accompanied by parents and 22 child respondents who were accompanied other than parents) by purposive sampling technique. The results showed that most (81.8\%) respondents who were accompanied by parents had mild criteria, while those who were accompanied by non-parents showed that most $(72.7 \%)$ had heavy criteria. The analysis result using mann whitney test revealed p-value $=0,000(\alpha \leq 0.05)$, which means there is a difference in the impact of hospitalization on preschool children accompanied by parents and other than parents in pediatric room of Amelia general hospital of Pare. Parents companion is very effected to child hospitalization, so nurses must approach the companion and the client it self so that the hospitalization runs well.

Keyword : parent, preschooler, hospitalization 
Dina Zakiyyatul Fuadah, dkk: Perbedaan Dampak Hospitalisasi Pada Anak Prasekolah Yang Didampingi Orang Tua Dan Selain Orang Tua

\section{PENDAHULUAN}

Penyakit dan Hospitalisasi seringkali menjadi krisis pertama yang harus dihadapi anak (Wong, Hockenberry-Eaton, Wilson, L.Winkelstein, \& Schwartz, 2009). Anak sangat rentan terhadap krisis penyakit dan hospitalisasi karena stress akibat perubahan dan keadaan sehat biasa dan rutinitas lingkungan dan anak memiliki jumlah mekanisme koping yang terbatas untuk menyelesaikan stressor. Stressor utama dari hospitalisasi adalah perpisahan, kehilangan kendali, cidera tubuh dan nyeri. Perawatan anak sakit selama dirawat di rumah sakit (hospitalisasi) menimbulkan krisis dan kecemasan tersendiri bagi anak dan keluarganya. Anak juga seringkali berhadapan dengan prosedur yang menimbulkan nyeri, kehilangan kemandirian dan berbagai hal yang tidak diketahui (Wong et al., 2009).

Berdasarkan fenomena di rumah sakit Amelia Pare ketika anak di rawat inap, ada yang didampingi orang tua dan ada yang didampingi selain orang tua. Orang tua diharapkan dapat berpartisipasi dalam merawat anak yang sakit terutama dalam perawatan saat rawat inap di rumah sakit. Manusia sebagai makhluk sosial membutuhkan kehadiran manusia lain didalam kehidupan pribadi seseorang begitu diperlukan. Hal ini terjadi karena seseorang tidak mungkin memenuhi kebutuhan fisik maupun psikologisnya secara sendiri. Individu membutuhkan dukungan sosial baik yang berasal dari atasan, teman sekerja maupun keluarga (Ganster, Fusilier, \& Mayes, 1986).

Berdasarkan data WHO (2012) bahwa 3-10\% anak dirawat di Amerika Serikat baik anak usia toddler, prasekolah ataupun anak usia sekolah. Sedangkan di Jerman sekitar 3$7 \%$ dari anak toddler dan $5-10 \%$ anak prasekolah yang menjalani hospitalisasi (Purwandari, 2009). Di Indonesia sendiri jumlah anak yang dirawat pada tahun 2014 sebanyak $15,26 \%$ yaitu meliputi anak usia prasekolah dan anak usia sekolah (Badan Pusat Statistik, 2014). Penelitian yang dilakukan oleh Cristina et al. (2016) menunjukan persentase anak usia prasekolah (3-6 tahun) yang dirawat di rumah sakit sebanyak $52,38 \%$ sedangkan persentase anak usia sekolah (7-12 tahun) yakni 47,62\%. Hal ini menunjukan bahwa anak usia prasekolah lebih rentan terkena penyakit serta takut dan cemas saat mendapatkan perawatan di rumah sakit (Salmela, Salanterä, \& Aronen, 2009).

Hasil studi pendahuluan pada tanggal 31 Agustus 2019 di rumah sakit Amelia Pare Kediri, jumlah klien yang dirawat di ruang anak adalah 132 pasien, rata-rata $90 \%$ anak yang dirawat didampingi oleh orang tuanya. Berdasarkan observasi perawat ruangan yang dilakukan pada tanggal 31 Agustus 2020 ada $10 \%$ pasien anak-anak yang dirawat yang tidak didampingi oleh orang tuanya, mereka lebih mengalami stres baik dalam hal perawatan maupun psikologisnya. Dalam hal perawatan anak lebih sulit diajak bekerjasama misalnya dalam hal tindakan invasif seperti pemasangan infus, injeksi, pengambilan darah maka anak akan menolak tindakan dengan cara menarik ekstremitas sekuat tenaga, memukul bahkan akan menggigit orang disampingnya. Dalam hal psikologis, anak lebih tidak kooperatif misalnya anak menangis terus atau rewel.

Hospitalisasi sering terjadi pada anak diantaranya disebabkan karena lingkungan baru, stres, cemas karena perpisahan, kehilangan kendali, luka pada tubuh dan rasa nyeri, dan juga faktor dari orang tua dan juga tenaga Kesehatan. Anak usia prasekolah bila mengalami hospitalisasi maka akan menunjukan reaksi-reaksi perilaku seperti protes, putus asa dan regresi. Hal ini bisa dibuktikan dengan anak tampak tidak aktif, sedih, tidak tertarik pada lingkungan, tidak komunikatif, mundur ke perilaku sebelumnya misalnya dengan menghisap ibu jari, mengompol dan lain-lain dan juga perilaku seperti ketergantungan, menarik diri dan ansietas (Wong et al., 2009). Sikap regresi merupakan fenomena yang umum terjadi pada anak yang mengalami rawat inap. Sikap regresi pada kasus yang lebih ringan muncul dalam bentuk menangis, bersandar pada ibu dan menghisap jari serta pada yang agak lebih berat anak bisa menolak makan dan kemungkinan lain terjadinya ketergantungan seperti keinginan untuk terus diperhatikan dan tidak dapat tidur. Dampak hospitalisasi 
Dina Zakiyyatul Fuadah, dkk: Perbedaan Dampak Hospitalisasi Pada Anak Prasekolah Yang Didampingi Orang Tua Dan Selain Orang Tua

jika tidak segera diatasi maka anak akan menjadi stres, kehilangan kendali yang bisa menimbulkan regresi, anak akan cepat marah dan agresif, anak akan kehilangan otonominya dan pada akhirnya akan menarik diri dari hubungan interpersonal.

Sebagai perawat profesional yang bertugas dalam memberikan pelayanan kesehatan tidak terlepas dari pengetahuan perawat baik dalam tindakan prosedural maupun dalam hal pemberian edukasi kepada keluarga pasien yang mendampingi anaknya. Supaya anak tidak mengalami stres saat hospitalisasi maka perawat perlu meningkatkan partisipasi orang tua, rooming in, membuat ruang perawatan seperti situasi di rumah, memberikan terapi bermain, mempertahankan kegiatan rutin anak, mengusakan kebebasan bergerak, mencegah meminimalkan perlukaan tubuh dan rasa sakit (Wong et al., 2009). Hamalik (2011) menyebutkan bahwa orang tua berperan dalam bentuk perilaku terhadap anggota keluarga dalam kondisi tertentu dan bersikap sebagai orang yang bertanggung jawab dalam status keluarga sesuai status dan fungsi sosial. Pendampingan orang tua sangat dibutuhkan sekali terutama saat anak mengalami sakit terutama yang dirawat di rumah sakit atau dengan kata lain anak yang mengalami hospitalisasi.

Berdasarkan latar belakang diatas, peneliti tertarik untuk melakukan penelitian tentang perbedaan dampak hospitalisasi pada anak prasekolah (usia 3-6 tahun) yang didampingi orang tua dan selain orang tua di Ruang anak Rumah sakit Amelia Pare Kediri.

\section{TUJUAN PENELITIAN}

Adapun tujuan dari pelaksanaa penelitian ini adalah untuk mengidentifikasi perbedaan dampak hospitalisasi pada anak prasekolah yang didampingi orang tua dan selain orang tua di Ruang Anak Rumah Sakit Amelia Pare.

\section{METODE PENELITIAN}

Desain Desain penelitian yang digunakan
adalah desain komparatif dengan menggunakan pendekatan cross sectional.

Populasi dan Sampel

Populasi dalam penelitian ini adalah seluruh anak yang di rawat di ruang anak rumah sakit Amelia Pare pada periode Januari 2020 sebanyak 66 anak. Sampel diambil dengan tehnik purposive sampling. Jumlah responden 44 yang digunakan dalam penelitian ini.

\section{Tempat dan Waktu Penelitian \\ Penelitian dilakukan di ruang anak rumah sakit Amelia Pare Kediri, Jawa Timur.}

\section{Instrumen dan Prosedur Pengukuran}

Instrumen dalam penelitian ini dengan menggunakan lembar observasi tentang dampak hospitalisasi pada anak usia pra sekolah (3-6 tahun). Pengukuran dilakukan setelah anak dirawat 1 hari di ruang anak rumah sakit Amelia Pare.

\section{Analisa Data}

Data dikumpulkan dan selanjutnya dianalisa dengan uji statistik uji komparasi mann-whitney dengan nilai $\alpha=0,05$.

\section{HASIL PENELITIAN}

Hasil penelitian disajikan sebagai berikut:

\section{Tabel 1}

Karakteristik Responden $(\mathrm{n}=22)$

\begin{tabular}{cccc}
\hline & $\begin{array}{c}\text { Karakteristik Responden } \\
\text { Didampingi Orang Tua }\end{array}$ & $\begin{array}{c}\text { Didampingi } \\
\text { orang tua }\end{array}$ & $\begin{array}{c}\text { Tidak } \\
\text { Didampingi } \\
\text { orang tua }\end{array}$ \\
\cline { 3 - 4 } & $3-4$ th & $\mathrm{f}(\%)$ & $\mathrm{f}(\%)$ \\
\hline Usia Anak & $4-5$ th & $11(50)$ & $5(22,7)$ \\
& & $6(27,3)$ & $6(27,3)$
\end{tabular}


Dina Zakiyyatul Fuadah, dkk: Perbedaan Dampak Hospitalisasi Pada Anak Prasekolah Yang Didampingi Orang Tua Dan Selain Orang Tua

\begin{tabular}{|c|c|c|c|}
\hline & $5-6$ th & $5(22,7)$ & $11(50)$ \\
\hline \multirow[t]{2}{*}{ Jenis kelamin } & Laki-Laki & $9(40,9)$ & $12(54,5)$ \\
\hline & Perempuan & $13(59,1)$ & $10(45,4)$ \\
\hline \multirow[t]{4}{*}{ Anak ke } & Pertama & $10(45,5)$ & $9(40,9)$ \\
\hline & Kedua & $7(31,8)$ & $8(36,4)$ \\
\hline & Ketiga & $4(18,2)$ & $5(22,7)$ \\
\hline & $>$ Ketiga & $1(4,5)$ & $0(0)$ \\
\hline \multirow{4}{*}{ Jumlah Saudara } & 1 (anak tunggal) & $11(50)$ & $10(45,5)$ \\
\hline & 2 bersaudara & $7(31,8)$ & $7(31,8)$ \\
\hline & 3 bersaudara & $2(9,1)$ & $5(22,7)$ \\
\hline & $>3$ bersaudara & $2(9,1)$ & $0(0)$ \\
\hline \multirow[t]{3}{*}{ Tinggal bersama } & Orang tua & $22(100)$ & $9(40,9)$ \\
\hline & Sanak saudara & $0(0)$ & $3(13,6)$ \\
\hline & Kakek-nenek & $0(0)$ & $10(45,5)$ \\
\hline \multirow{2}{*}{$\begin{array}{l}\text { Jenis kelamin } \\
\text { pendamping }\end{array}$} & Laki-laki & $1(4,5)$ & $2(9,1)$ \\
\hline & Perempuan & $21(95,5)$ & $20(90.9)$ \\
\hline \multirow[t]{4}{*}{ Usia pendamping } & $<25$ tahun & $6(27,3)$ & $0(0)$ \\
\hline & 26-35 tahun & $12(54,5)$ & $2(9,1)$ \\
\hline & 36-45 tahun & $4(18,2)$ & $7(31,8)$ \\
\hline & $>45$ tahun & $0(0)$ & $13(59,1)$ \\
\hline \multirow[t]{4}{*}{ Pekerjaan pendamping } & Buruh & $3(13,6)$ & $4(18,2)$ \\
\hline & Wiraswasta & $9(40,9)$ & $4(18,2)$ \\
\hline & PNS & $0(0)$ & $1(4,5)$ \\
\hline & IRT & $10(45,4)$ & $13(59,1)$ \\
\hline \multirow[t]{3}{*}{$\begin{array}{l}\text { Tingkat pendidikan } \\
\text { pendamping }\end{array}$} & $\begin{array}{l}\text { pendidikan dasar (SD, } \\
\text { SMP) }\end{array}$ & $6(27,3)$ & $15(68,2)$ \\
\hline & $\begin{array}{l}\text { pendidikan menengah } \\
\text { (SMA) }\end{array}$ & $15(68,2)$ & $6(27,3)$ \\
\hline & $\begin{array}{l}\text { pendidikan tinggi (D3, } \\
\text { S1) }\end{array}$ & $1(4,5)$ & $1(4,5)$ \\
\hline
\end{tabular}

Hasil penelitian untuk karakteristik responden pada anak yang didampingi orang tua diperoleh hasil sebagai berikut: karakteristik usia responden didapatkan setengah 50\% responden berusia 3-4 tahun, jenis kelamin responden didapatkan lebih dari setengah $(59,1 \%)$ dari responden berjenis kelamin perempuan, pada karakteristik anak keberapa didapatkan hampir setengah $(45,5 \%)$ responden merupakan anak pertama. Jenis kelamin pendamping didapatkan hampir seluruh $(95,5 \%)$ responden berjenis kelamin perempuan. Karakteristik usia pendamping lebih dari setengah (54,5\%) responden berusia 26-35 tahun, pada pekerjaan pendamping orang tua didapatkan kurang dari setengah $(45,5 \%)$ pekerjaan IRT, tingkat pendidikan pendamping didapatkan sebagai besar $(68,2 \%)$ responden pendidikan menengah (SMA). Pada karakteristik selalu didampingi selama perawatan didapat seluruh (100\%) responden menjawab ya. Hasil penelitian untuk karakteristik responden pada anak yang tidak didampingi orang tua diperoleh hasil sebagai berikut : karakteristik usia responden didapatkan kurang dari setengah $(27,3 \%)$ responden berusia 4-5 tahun, jenis kelamin responden didapatkan lebih dari setengah $(54,5 \%)$ dari responden berjenis kelamin laki-laki, pada karakteristik anak keberapa didapatkan hampir setengah $(40,9 \%)$ responden merupakan anak pertama. Jenis kelamin pendamping didapatkan hampir seluruh $(90,9 \%)$ responden berjenis kelamin perempuan. Karakteristik usia pendamping lebih dari setengah $(59,1 \%)$ responden berusia $>45$ tahun, pada pekerjaan pendamping orang tua didapatkan lebih dari setengah $(59,1 \%)$ pekerjaan IRT, tingkat pendidikan pendamping didapatkan sebagai besar $(68,2 \%)$ responden pendidikan dasar (SD,SMP). 
Dina Zakiyyatul Fuadah, dkk: Perbedaan Dampak Hospitalisasi Pada Anak Prasekolah Yang Didampingi Orang Tua Dan Selain Orang Tua

Tabel 2

Karakteristik Pendamping Selain Orang Tua $(n=22)$

\begin{tabular}{llc}
\hline \multicolumn{2}{c}{ Karakteristik } & $\mathrm{f}(\%)$ \\
\hline $\begin{array}{l}\text { Hubungan } \\
\text { pendamping } \\
\text { dengan anak }\end{array}$ & Kakek-nenek & $17(77,3)$ \\
& & \\
& Sanak saudara & $2(9,1)$ \\
& Pengasuh & $3(13,6)$ \\
\hline Tinggal berapa & Sejak lahir & $1(4,5)$ \\
lama & $<1$ tahun & $4(18,2)$ \\
& $1-2$ tahun & $6(27,3)$ \\
& $>2$ tahun & $11(50)$ \\
\hline $\begin{array}{l}\text { Alasan orang tua } \\
\text { tidak }\end{array}$ & Meninggal & \\
mendampingi & & $4(18,2)$ \\
& Bekerja & $17(77,3)$ \\
& Sakit & $1(4,5)$ \\
\hline
\end{tabular}

Pada karakteristik hubungan pendamping dengan anak didapatkan sebagian besar $(77,3 \%)$ responden kakeknenek. Tinggal bersama pendamping didapatkan setengah $(50 \%)$ responden tinggal bersama $>2$ tahun. Alasan tidak mendampingi didapatkan sebagian besar $(77,3 \%)$ karena alasan bekerja.

Tabel 3

Perbedaan Dampak Hospitalisasi Pada Anak Yang Didampingi dan Tidak Didampingi Orang Tua $(\mathrm{n}=22)$

\begin{tabular}{lccc}
\hline \multicolumn{1}{c}{ Variabel } & $\mathrm{f}(\%)$ & Mean & $\begin{array}{c}\mathrm{p}- \\
\text { value }\end{array}$ \\
\hline $\begin{array}{l}\text { Dampak } \\
\text { hospitalisasi yang } \\
\text { didampingi orang } \\
\text { tua }\end{array}$ & & & \\
$\quad \begin{array}{l}\text { Ringan } \\
\text { Sedang }\end{array}$ & $18(81,8)$ & & \\
$\quad$ Berat & $4(18,2)$ & & \\
\hline $\begin{array}{l}\text { Dampak } \\
\text { hospitalisasi }\end{array}$ & $0(0)$ & & 0,000 \\
didampingi selain & & & \\
orang tua & & & \\
$\quad \begin{array}{l}\text { Ringan } \\
\text { Sedang }\end{array}$ & $0(0)$ & & \\
Berat & $6(27,3)$ & \\
\hline
\end{tabular}

Berdasarkan hasil penelitian yang terdapat pada tabel diatas menunjukkan bahwa sebagian besar $(81,8 \%)$ responden sebanyak 18 responden yang didampingi orang tua memiliki dampak hospitalisasi kriteria ringan. Berdasarkan hasil penelitian yang terdapat pada tabel diatas menunjukkan bahwa sebagian besar $(72,7 \%)$ responden sebanyak 16 responden yang didampingi selain orang tua memiliki dampak hospitalisasi kriteria berat. Hasil uji statistik menggunakan mann whitney didapatkan nilai $\rho$-value $=0,000<\alpha=0.05$. Hal ini menunjukkan bahwa $\mathrm{H}_{1}$ diterima, artinya ada Perbedaan dampak hospitalisasi pada anak prasekolah usia (3-6 tahun) yang didampingi orang tua dan selain orang tua di Ruang Anak Rumah Sakit Amelia Pare, dengan nilai perbedaan Mean $=12.05$ (orang tua), 32.95 (selain orang tua) yang berarti perbedaan dampak hospitlasisasi pada anak yang tidak diampingi orang tua lebih besar dibandingkan dengan yang didampingi orang tua.

\section{PEMBAHASAN}

Identifikasi Dampak Hospitalisasi Anak Prasekolah (Usia 3-6 Tahun) Yang Didampingi Orang Tua di Ruang Anak Rumah Sakit Amelia Pare

Berdasarkan hasil penelitian menunjukkan bahwa sebagian besar $(81,8 \%)$ respondenyang didampingi orang tua memiliki dampak hospitalisasi kriteria ringan, sebagian kecil $(18,2 \%)$ responden kriteria sedang dan tidak satupun responden (0\%) memiliki dampak hospitalisasi kriteria berat. Terkait dampak hospitalisasi sebagaimana menurut Sulistiyani, Nurhayati, \& Nurfauziah (2018), menyebutkan bawha hospitalisasi akan menyebabkan anak mengalami trauma jangka pendek maupun jangka panjang. Dampak negatif ini berkaitan dengan lamanya dan banyaknya jumlah pasien, berbagai prosedur invasif serta pendampingan orang tua. Gejala yang timbul berupa respon regresi, cemas terhadap perpisahan, apatis, ketakutan, gangguan tidur. Perawatan anak sakit selama dirawat di Rumah Sakit (hospitalisasi) menimbulkan krisis dan kecemasan tersendiri bagi anak dan keluarganya. Anak juga seringkali berhadapan dengan prosedur yang menimbulkan nyeri, kehilangan kemandirian dan berbagai hal yang tidak diketahui (Wong et al., 2009). Orang tua diharapkan dapat berpartisipasi dalam merawat anak yang sakit terutama dalam 
Dina Zakiyyatul Fuadah, dkk: Perbedaan Dampak Hospitalisasi Pada Anak Prasekolah Yang Didampingi Orang Tua Dan Selain Orang Tua

perawatan saat rawat inap di Rumah Sakit. Manusia sebagai makhluk sosial membutuhkan kehadiran manusia lain didalam kehidupan pribadi seseorang begitu diperlukan. Hal ini terjadi karena seseorang tidak mungkin memenuhi kebutuhan fisik maupun psikologisnya secara sendiri. Individu membutuhkan dukungan sosial baik yang berasal dari atasan, teman sekerja maupun keluarga (Ganster et al., 1986).

Dampak hospitalisasi pada responden yang didampingi oleh orang tua memiliki dampak hospitalisasi kriteria ringan, hal ini karena orang tua memberikan perhatian pada anak dengan mendampinginya, orang tua berperilaku lebih dalam memperhatikan anaknya sebagai wujud orang yang bertanggung jawab sesuai fungsi sosial yang memang harus mendampingi anaknya manakala dibutuhkan anak terutama bagi anak yang mengalami hospitalisasi, dengan perhatian yang diberikan orang tua maka dampak hospitalisasinya hanya sebatas berupa dampak ringan, meskipun anak dalam kondisi lingkungan yang mengharuskan anak untuk menyesuaikan diri dengan lingkungannya pada saat dirawat di rumah sakit, sebab adanya pendampingan orang tua, perasaaan anak akan lebih tenang, tidak sedih, tidak gugup berbicara meskipun mengalami berbagai perasaan yang sangat tidak menyenangkan, seperti, takut, cemas, sedih, marah dan nyeri.

Terdapatnya dampak hospitalisasi anak secara tidak langsung juga dipengaruh oleh faktor usia anak, dan jenis kelamin pendamping, Jenis kelamin pendamping perempuan (ibu), karena perempuan lebih memahami apa yang dibutuhkan anak, perempuan lebih sabar dibandingkan lakilaki, perempuan suka melindungi anak terutama anak saat sedih, anak biasanya lebih suka berkomunikasi dengan orang yang membuatnya terbiasa dalam kesehariannya yaitu ibu.

Dalam perkembangannya anak prasekolah (usia 3-6 tahun) mengalami perubahan fisiologis dan perubahan biologis dimana keduanya berpengaruh didalam sektor perkembangan yang meliputi perilaku sosial, gerakan motorik halus maupun kasar, bahasa. Reaksi hospitalisasi pada anak prasekolah (usia 3-6 tahun) berkaitan erat dengan tumbuh kembang anak di usia tersebut. Anak usia prasekolah (3-6 tahun) bereaksi terhadap hospitalisasi sesuai dengan sumbernya. Sumber stres yang utama adalah cemas akibat perpisahan. Respon perilaku anak sesuai dengan tahapannya, yaitu tahap protes, putus asa, dan pengingkaran (denial). Pada tahapan protes, perilaku yang ditunjukan adalah menangis kuat, menjerit memanggil orang tua atau menolak perhatian yang diberikan orang lain. Pada tahap putus asa, perilaku yang ditunjukan adalah menangis berkurang, anak tidak aktif, kurang menunjukan minat untuk bermain dan makan, sedih dan apatis. Pada tahap pengingkaran, perilaku yang ditunjukan adalah secara samar mulai menerima perpisahan, membina hubungan secara dangkal, dan anak terlihat mulai menyukai lingkungannya. Sumber stres saat hospitalisasi antara lain akibat perpisahan, kehilangan control, cedera dan nyeri tubuh akibat prosedur invasif. Respon perilaku pada anak usia $3-6$ tahun adalah regresi, ketergantungan, perasaan takut, rasa bersalah serta respon fisiologis

\section{Identifikasi Dampak Hospitalisasi Anak Prasekolah (Usia 3-6 Tahun) Yang Didampingi Selain Orang Tua di Ruang Anak Rumah Sakit Amelia Pare}

Berdasarkan hasil penelitian menunjukkan bahwa sebagian besar $(72,7 \%)$ responden yang didampingi selain orang tua orang tua memiliki dampak hospitalisasi kriteria berat, kurang dari setengah $(27,3 \%)$ responden kriteria sedang dan tidak satupun responden $(0 \%)$ memiliki dampak hospitalisasi kriteria ringan. Hospitalisasi sebagai suatu keadaan krisis pada anak, saat anak sakit dan dirawat di rumah sakit. Keadaan ini terjadi karena anak berusaha untuk beradaptasi dengan lingkungan asing dan baru yaitu rumah sakit, sehingga kondisi tersebut menjadi faktor stressor bagi anak baik terhadap anak maupun orang tua dan keluarga (Wong et al., 2009). Hospitalisasi dapat merupakan satu penyebab stres bagi anak dan keluarganya. Tetapi tingkat stressor terhadap penyakit dan hospitalisasi tersebut berbeda menurut anak secara individu. seorang anak menganggap hal itu sebagai hal yang biasa tetapi yang lainnya 
menganggap hal tersebut sebagai stressor. Dan dampak jika hospitalisasi tidak segera diatasi maka anak akan menjadi stres, kehilangan kendali yang bisa menimbulkan regresi, anak akan cepat marah dan agresif, anak akan kehilangan otonominya dan pada akhirnya akan menarik diri dari hubungan interpersonal

Berdasarkan hasil penelitian dampak hospitalisasi anak pada anak yang didampingi selain orang tua menunjukkan bahwa sebagian besar responden memiliki dampak hospitalisasi dengan kriteria berat, hal ini terjadi karena anak yang didampingi selain orang tua akan memiliki stressor yang lebih berat sebagai respon perilaku anak berupa protes, putus asa, dan pengingkaran (denial) yang ditunjukkan dengan menangis kuat, menjerit dan menolak perhatian yang diberikan orang lain termasuk perhatian dari pendampingnya saat hospitalisasi. Emosi responden cenderung bercampur aduk pada saat fase protes dimana kebanyakan responden mengalami gejala seperti sering menangis, tidak tenang, pucat, sering terbangun tengah malam dan gelisah, namun pada fase pemisahan diri responden merasa ringan dan terlihat tenang ketika harus menginap dan berada di ruangan rawat inap. Hal ini terjadi karena anak merasa takut mengenai peralatan medis misalnya takut dengan jarum suntik dan ruangan rumah sakit waktu gelap, anak takut saat didekati perawat, memalingkan wajah ketika perawat menghampiri. Oleh karena itu pendamping anak sangat menentukan beratnya dampak hospitalisasi yang dialami anak saat rawat inap. Anak kehilangan kemampuannya untuk mengontrol diri sehingga menyebabkan anak memiliki dampak hospitalisasi dalam kategori berat yang ditunjukkan dengan adanya bentuk protes yang banyak terjadi seperti anak menangis dan berteriak, anak tampak gelisah menghadapi perawat memalingkan wajah dan juga anak anak enggan berinteraksi, selain itu juga terjadi penyangkalan seperti anak ketakutan ketika dia berada diruangan dan sulit untuk berkonsentrasi.

Berdasarkan data umum pada karakteristik responden sebagian besar (77,3\%) didampingi kakek-nenek dan pada karakteristik usia responden yang didampingi selain orang tua didapatkan kurang dari setengah $(27,3 \%)$ responden berusia 4-5 tahun. Anak yang didampingi selain orang tua misalnya didampingi kakek nenek maka mereka akan tidak berani mengungkapkan apa yang mereka rasakan, mereka takut jika apa yang diungkapkan tidak disetujui atau dilaksanakan oleh pendampingnya, berbeda sekali jika mereka didampingi oleh orang tuanya sendiri yang mana setiap apa yang mereka ungkapkan akan didengarkan dengan baik. Sehingga anak mempersepsikan sakit sebagai hukuman. Sehingga menimbulkan reaksi agresif seperti menolak makan, sering bertanya, menangis perlahan, tidak kooperatif terhadap petugas kesehatan. Oleh karena itu petugas kesehatan harus bisa melakukan pendekatan sebaik mungkin baik terhadap pendamping maupun klien anak itu sendiri. Perawat bisa melakukan pendekatan ke anak dengan menciptakan suasana yang menyenangkan seperti dengan mengajak bernyanyi, melihatkan permainan anak-anak yang tersedia, mengajak melihat televisi film kartun, sehingga nantinya anak bisa kooperatif terhadap petugas saat memberikan pelayanan atau tindakan keperawatan maupun dengan pendampingnya pada saat mendampingi setiap harinya.

Didapatkannya kurang dari setengah responden berusia 4-5 tahun, hal ini disebabkan pada usia prasekolah sudah dapat dipastikan anak tersebut akan mengalami dampak hospitalisasi bila dirawat di rumah sakit, yang ditandai dengan sering menangis dan tidak kooperatif dengan petugas kesehatan terutama saat mengambil tindakan medis. Sehingga seharusnya pendamping selain orang tua dan petugas kesehatan dapat menciptakan suasana yang menyenangkan seperti mengajak berbicara, bercerita atau bermain menggambar sebagai upaya mengalihkan perhatian anak pada suaana yang menyenangkan sehingga bentuk dampak hospitalisasi yang ada dapat berkurang. Selain hal tersebut adanya dampak hospitalisasi juga dipengaruhi adanya faktor pendamping sebagaimana sebagian besar anak yang tidak didampingi orang tua mereka didampingi oleh kakeknenek membuat kenyamanan anak kurang 
maksimal dibandingkan dengan anak yang didampingi orang tuanya, anak merasa adanya dampak hospitalisasi tersebut sebagai hukuman sehingga anak bereaksi menolak yang ditunjukkan menangis dan tidak kooperatif pada petugas kesehatan hal tersebut sebagai bentuk dampak hospitalisasi.

Pada data umum diketahui bahwa karakteristik jenis kelamin responden didapatkan lebih dari setengah $(54,5 \%)$ dari responden berjenis kelamin laki-laki. Menurut Wong et al. (2009) anak yang mengalami hospitalisasi sering menjadi krisis pertama pada anak-anak yang harus dihadapi. Konsep anak terhadap sakit bahkan lebih penting daripada usia dan intelektual untuk memprediksi tingkat adjustment sebelum hospitalisasi. Hal tersebut mungkin atau mungkin tidak dipengaruhi oleh lamanya kondisi penyakit atau hospitalisasi (Wong et al., 2009). Anak perempuan pada umumnya lebih adaptif terhadap stressor dibanding anak laki-laki. Stimulus yang mengawali atau mencetuskan perubahan disebut stressor. Stressor menunjukkan suatu kebutuhan yang tidak terpenuhi dan kebutuhan tersebut bisa saja kebutuhan fisiologis, psikologis, sosial, lingkungan, perkembangan, spiritual, atau kebutuhan kultural (Potter, Perry, Stockert, \& Hall, 2012). Selama hospitalisasi anak-anak mengalami dampak hospitalisasi mereka membutuhkan dukungan psikologis seperti perhatian dari orang tua dan keluarga, kebutuhan sosial seperti bertemu dengan teman-temannya, kebutuhan lingkungan seperti anak ingin berada di lingkungan rumahnya dan kebutuhan perkembangan seperti bermain dengan teman sebaya. Anak laki-laki merupakan salah satu faktor risiko yang membuat anak-anak tertentu lebih mudah tersinggung dibandingkan anak lain dalam kondisi stress saat hospitalisasi (Wong et al., 2009).

Menurut pendapat peneliti didapatkan bahwa sebagian besar responden berjenis kelamin laki-laki, hal ini terjadinya dampak hospitalisasi pada anak dapat dialami oleh semua anak baik laki-laki mupun perempuan bentuk dampak hospitalisasi yang dialami anak pada umumnya dikarenakan adanya kondisi penyakit, kondisi ruang rumah sakit dan berpisah dengan orang tua dan saudara kandung, selain itu hospitalisasi anak lakilaki merupakan salah satu faktor resiko terjadinya bentuk dampak adanya hospitalisasi yang ditampilkan oleh anak pada saat hospitalisasi.

Perbedaan Dampak Hospitalisasi Pada Anak Prasekolah Usia (3-6 Tahun) Yang Didampingi Orang Tua Dan Selain Orang Tua di Ruang Anak Rumah Sakit Amelia Pare

Hasil analisis penelitian perbedaan dampak hospitalisasi pada anak prasekolah (usia 3-6 tahun) yang didampingi orang tua dan selain orang tua di ruang anak rumah sakit Amelia Pare, dari hasil uji statistik menggunakan mann whitney didapatkan nilai $\rho$-value $=0,000<\alpha 0.05$ hal ini menunjukkan bahwa $\mathrm{H}_{1}$ diterima, artinya ada Perbedaan dampak hospitalisasi pada anak prasekolah (usia 3-6 tahun) yang didampingi orang tua dan selain orang tua di ruang anak rumah sakit Amelia Pare, dengan nilai perbedaan mean $=12.05$ (orang tua), 32.95 (selain orang tua) yang berarti perbedaan dampak hospitlasisasi pada anak yang dampingi selain orang tua lebih besar dibandingkan dengan yang didampingi orang tua. Sedangkan berdasarkan distribusi pada tabel silang menunjukkan bahwa sebagian besar $(81,8 \%)$ responden sebanyak 18 responden yang didampingi orang tua memiliki kriteria ringan. Sedangkan yang didampingi selain orang tua menunjukkan sebagian besar $(72,7 \%)$ responden 16 responden kriteria berat.

Hospitalisasi seringkali menjadi krisis pertama yang harus dihadapi anak (Wong et al., 2009). Anak sangat rentang terhadap krisis penyakit dan hospitalisasi karena stress akibat perubahan dan keadaan sehat biasa dan rutinitas lingkungan dan anak memiliki jumlah mekanisme koping yang terbatas untuk menyelesaikan stressor (kejadian-kejadian yang menimbulkan stress). Stressor utama dari hospitalisasi adalah perpisahan, kehilangan kendali, cidera tubuh dan nyeri. Menurut Fadlian N. \& Konginan (2015), faktor yang mempengaruhi hospitalisasi pada anak adalah berpisah dengan orang tua dan 
Dina Zakiyyatul Fuadah, dkk: Perbedaan Dampak Hospitalisasi Pada Anak Prasekolah Yang Didampingi Orang Tua Dan Selain Orang Tua

saudara kandung, fantasi-fantasi dan unrealistic anxietas, gangguan kontak sosial jika pengunjung tidak diizinkan menjenguk, nyeri dan komplikasi akibat pembedahan atau penyakit, prosedur yang menyakitkan, takut akan cacat dan kematian. Sering terjadi fenomena disaat anak mengalami hospitalisasi, mereka ada yang didampingi orang tua dan ada yang didampingi selain orang tua, kondisi tersebut selama proses perawatan anak sakit selama dirawat di rumah sakit menimbulkan krisis dan kecemasan tersendiri bagi anak dan keluarganya. Anak juga seringkali berhadapan dengan prosedur yang menimbulkan nyeri, kehilangan kemandirian dan berbagai hal yang tidak diketahui (Wong et al., 2009).

Sesuai hasil penelitian didapat nilai nilai $\rho=0,000<\alpha 0.05$ ada perbedaan dampak hospitalisasi pada anak prasekolah (usia 3-6 tahun) yang didampingi orang tua dan selain orang tua di ruang anak rumah sakit Amelia Pare. Hal ini menunjukkan bahwa pendampingan yang diberikan pada anak memang benar dapat berdampak pada hospitalisasi yang terjadi pada anak, anak yang didampingi orang tua akan memiliki dampak hospitalisasi ringan dibandingkan dengan akan yang didampingi selain orang tua. Berdasarkan hasil analisis tersebut dapat dijelaskan bahwa, anak yang mendapatkan pendampingan dari orang tua lebih merasa tenang dan dapat meminimalisir stressor, sebagaimana dalam pendampingan yang diberikan orang tua pada anak yang tadinya mereka cemas dan gelisah atau takut lebih dapat mengontrol diri dengan adanya perhatian yang diberikan orang tua maka dampak hospitalsisasi menjadi ringan seperti perasaaan anak akan lebih tenang meskipun mengalami berbagai perasaan yang sangat tidak menyenangkan, selain itu juga teknik komunikasi perawat yang terapeutik membuat anak mengerti dan anak menjadi tenang, dan juga didukung dengan penampilan tenaga medis yang rapi atau baik membuat anak menjadi kooperatif saat dilakukan tindakan perawatan, sehingga tindakan keperawatan bisa dilakukan secara maksimal.

\section{KESIMPULAN}

Implikasi

Sebagian besar responden yang didampingi orang tua memiliki dampak hospitalisasi kriteria ringan. Selainitu, sebagian besar responden yang didampingi selain orang tua memiliki dampak hospitalisasi kriteria berat. Hasil analisis menunjukkan ada perbedaan dampak hospitalisasi pada anak prasekolah usia (3-6 tahun) yang didampingi orang tua dan selain orang tua di ruang anak rumah sakit Amelia Pare. Anak yang didampingi selain orang tua akan memiliki dampak hospitalasi yang lebih berat dibandingkan dengan anak yang didampingi orang tua, hal ini karena pendamping selain orang tua kurang maksimal dalam memberikan dukungan secara spikologis bila dibandingkan dengan dukungan yang diberikan oleh orang tua kandung, pedampingan yang diberikan pada anak oleh pendamping selain orang tua tentu saja akan berbeda dengan bentuk pendampingan yang diberikan oleh orang tua kandung, pendampingan orang tua juga menjadi pendukung psikologis kesembuhan anak yang sedang dirawat. Dampak hospitalisasi perlu ditangani sedini mungkin salah satunya dapat diberikan dengan menghadirkan pendamping yang dekat dengan anak terutama orang tua.

\section{Keterbatasan}

Keterbatasan dalam penelitian ini adalah dampak Stress akibat hospitalisasi pada anak tidak bisa di deskripsikan dengan baik. Sehingga dibutuhkan penelitian dengan desain lainnya untuk dapat memberikan pengukuran stress hospitalisasi pada anak yang lebih spesifik.

\section{DAFTAR PUSTAKA}

Badan Pusat Statistik. (2014). Survei Sosial Ekonomi Nasional (SUSENAS) Modul Ketahanan Sosial. Jakarta.

Cristina, I., Lemos, S., Gomes, L., Delmondes, G. D. A., Brasil, A. X., Laysa, P., ... Fernandes, G. P. (2016). Therapeutic Play Use in Children under the Venipucture: A Strategy for Pain Reduction. American Journal of Nursing Research, 4(1), 1-5. 
Dina Zakiyyatul Fuadah, dkk: Perbedaan Dampak Hospitalisasi Pada Anak Prasekolah Yang Didampingi Orang Tua Dan Selain Orang Tua

Fadlian N., \& Konginan, A. (2015). Hospitalisasi pada Anak. Child Hospitalization. Suraba: Universitas Airlangga.

Ganster, D. C., Fusilier, M. R., \& Mayes, B. T. (1986). Role of social support in the experience of stress at work. $J \mathrm{Appl}$ Psychol, 71(1), 102-110.

Hamalik, O. (2011). Psikologi Belajar dan Mengajar. Bandung: Sinar Baru Algesindo.

Potter, P. A., Perry, A. G., Stockert, P. A., \& Hall, A. M. (2012). Fundamentals of Nursing (8th ed.). St. Louis Missouri: Mosby, Inc.

Purwandari, H. (2009). Pengaruh Terapi Seni Dalam Menurunkan Tingkat Kecemasan Anak Usia Sekolah yang Menjalani Hospitalisasi di Wilayah Kabupaten Banyumas. Universitas Indonesia.

Salmela, M., Salanterä, S., \& Aronen, E. (2009). Child-reported hospital fears in 4 to 6-year-old children. Pediatr Nurs, 35(5), 269-276.

Sulistiyani, E., Nurhayati, \& Nurfauziah. (2018). Hubungan Dukungan Keluarga dengan Tingkat Kecemasan Anak Usia Sekolah yang Mengalami Tindakan Invasif di Ruang Anak RSUD dr. R. Soedjono Selong Lombok Timur. Jurnal Prima, 4(2), 25-42.

WHO. (2012). World Health Statistics. World Health Organization. Geneva.

Wong, D. L., Hockenberry-Eaton, M., Wilson, D., L.Winkelstein, M., \& Schwartz, P. (2009). Buku Ajar Keperawatan Pediatrik. Jakarta: EGC. 